\title{
Consumer Empowerment: A Foucauldian Interpretation
}

By

\author{
Avi Shankar ${ }^{1}$, Hélène Cherrier ${ }^{2}$ and Robin Canniford ${ }^{3}$
}

\author{
Revised Submission to \\ European Journal of Marketing \\ Special Edition on Consumer Empowerment \\ Guest Editor: Professor Len Tui Wright
}

\footnotetext{
${ }^{1}$ Address for correspondence: Senior Lecturer in Marketing \& Consumer Research, Department of Management, School of Business and Economics, University of Exeter, EX4 4PU. Email A.Shankar@exeter.ac.uk

${ }^{2}$ Lecturer in Marketing, Faculty of Economics and Business, University of Sydney, NSW 2006, Australia. Email h.cherrier@econ.usyd.edu.au

${ }^{3}$ Doctoral Candidate, Department of Management, School of Business and Economics, University of Exeter, EX4 4PU. Email R.Canniford@exeter.ac.uk
} 


\begin{abstract}
Purpose - The purpose of this paper is to question the taken for granted assumptions that underpin a liberal or lay view of consumer empowerment implicit to this special edition. In particular, the idea that it benefits consumers to have more choice is questioned. Design/methodology/approach - The key constructs of Michel Foucault - disciplinary power, governmentality and technologies of self - are used to argue that people can never escape from the operation of power. Rather it is shown how power operates to produce consumers.
\end{abstract}

Findings - The liberal view of the empowerment of consumers through choice is questioned. Rather we suggest the opposite; that choice is a disciplinary power and that more and more choice can lead to choice paralysis. The contemporary phenomenon known as blogging is described as a Foucauldian technology of self. Managerial implications are discussed.

Originality/value - The value of a Foucauldian inspired theory of empowerment is that it represents a more sophisticated understanding of the fluidity of power relationships between producers and consumers than can be captured by a liberal view of power and empowerment.

Key words: Consumer Empowerment, Foucault, Blogging, Choice. 


\section{Introduction}

In recent years we have seen the emergence of critical inquiry within the marketing discipline (e.g. Brownlie et al 1999b; Burton, 2001; Morgan, 1992; Murray and Ozanne, 1991), management, and organization studies (e.g. Alvesson and Deetz, 2000; Alvesson and Wilmott, 1992). The theoretical and conceptual foundations of critical inquiry span theories and constructs from feminism, Marxism and psychoanalysis. Regardless of the diversity of approach, all critical inquiry can be characterized as subjecting 'truth claims... to careful and consistent scrutiny' (Brownlie et al 1999a: p. 10). In line with the materialization of critical inquiry within the marketing discipline and in conjunction with this special edition, we propose to critically examine the notion of consumer empowerment.

An assumption that underpins this special edition, is that at the beginning of the $21^{\text {st }}$ century we are in the midst of a shift in power from producers to consumers (Samli, 2001) and that this shift has been beneficial, especially for consumers. Implicit to this perspective is a liberal humanist, traditional or lay view of empowerment. However, when following Boje and Rosile's (2001) view that any discussion of empowerment is a discussion of power and considering one of the $20^{\text {th }}$ century's foremost theoreticians of power, Michel Foucault, the liberal notion of consumer empowerment is challenged. For Foucault, power is omnipresent and constitutive of our very existence; there is no owning, acquiring, escaping or losing it. Power is inscribed in discourses and language structures, operating through all our social practices, producing subjects - in our case consumers. Although the influence of Foucault's work has been felt across the social sciences, his ideas have not had much impact in the marketing field (for exceptions see 
for example Desmond, 2003; Hodgson, 2001; Kasabov, 2004; Marsden, 2003). Where his work has been used, only one of his key constructs tends to be discussed - disciplinary power (Desmond, 2003; Kasabov, 2004; Marsden, 2003). However, Foucault's work, like that of all great thinkers, was always in progress, and his conception of disciplinary power changed over the course of his career towards a more sophisticated understanding of the fluidity of power relations. Our aim in this paper is to reconsider the notion of consumer empowerment through the key Foucauldian constructs of disciplinary power, governmentality and technologies of self. Through these constructs we demonstrate that consumer empowerment is liberating and disciplining. We conclude the paper by examining some implications for marketing theory and practice, and directions for further research that emerge when a traditional, liberal humanist view of empowerment is contrasted with this Foucauldian perspective on empowerment.

\section{(Neo)Liberal Notions of Consumer Empowerment}

A traditional or liberal humanist version of power and empowerment (e.g. Berlin, 1969) acknowledges particular sites of antagonisms such as freedom from a particular phenomenon or constraint, or freedom to take any particular action. This objectified view of power suggests that power may be exercised by one party over another and that empowerment may involve the loss of power by one party to another or acquisition of power by one party over another (see Lincoln et al, 2002 for a discussion of the etymology of empowerment). These articulations recognize an opposition between relatively identifiable degrees of power and sets of relationships and also conceptualize 
power in such a way that there is always the possibility for human relationships not to be mediated by power.

Accordingly, a traditional view of consumer empowerment would suggest that we have witnessed a shift in power from producers to consumers. Moreover, people when conceptualised as consumers, have been given, or alternatively have acquired more power, control and influence over what they consume. This perspective raises a number of subsidiary questions: if consumers have more power who has given it to them? Where has it come from? And how is this power manifested? We take the position that modern consumers are portrayed as having an unprecedented power to choose, to customize the goods and services that they want, to avoid the undesired ones, and to shop around for the best price-quality combinations. This consumer power reallocates the product-push approach to a consumption-pull strategy and reconfigures the supply chain to a demand chain that supposedly provides consumers with exactly what they want. Under this view we could suggest that marketing per se embodied in its foundational axiom, the marketing concept, is the rhetorical legitimization that people, by becoming consumers, may be empowered: empowerment is thus equated to the power to exercise choice.

When marketing is conceptualised as a tool for performing a market economy (Cochoy, 1998), as opposed to a managerial function or philosophy, then the consumer becomes an ideological necessity. The neo-liberal political economy of the Right, that relies on long-standing modernist axioms of freedom and autonomy regards capitalist development as delivering freedom through choice. Choice in this context involves the creation of markets, consumers and consumption (Dholakia and Dholakia, 1985). Choice as a manifestation of peoples' ability to exercise free-will, thereby demonstrating their 
autonomy and self-determination has become normalized - at least in advanced industrialized economies - with a long intellectual heritage that can be traced back to the writings of the ancient Greek philosophers like Plato (Schwartz, 2004). Ultimately, the point of having all this choice is so that people can improve the quality of their lives.

Why should this form of political economy suggest that consumers have gained power over producers? To be free or liberated from any dependency - a reading of what it is to be empowered - is conflated to a person's ability to exercise choice in the marketplace by becoming or being a consumer. Increasing competition in the marketplace stimulates technological change and productive efficiency and thereby manufactures a greater array of goods and services for the consumer, ergo greater freedom to choose and less dependency on any one producer. Thus it is through markets and increased consumption that progress - the overarching modernist axiom (Brown, 1995) - can empower consumers. From such a perspective, perfect competition fully empowers the consumer.

This view of consumers as choosers has its origins in neo-classical economics that has provided not only the rationale for perpetual economic growth as a surrogate measure of improving standards of living, but also the intellectual justification for the reliance on markets in structuring the use of resources. The neo-liberal political agenda of Reaganomics and Thatcherism popularised the appeal of an individual's freedom to choose. As a result, it could be argued that neo-classical economics hand-in-hand with neo-liberalism has made the case to relocate power to the individual, or to be more precise, to the consumer (Friedman and Friedman, 1962; 1980). 
Implicit to this neo-classical view is that consumers 'know' what they want in order to maximize their utility - all they have to do is decide what product offering is going to achieve this within their budgetary constraints. Consumers are constructed as rational utility maximisers, because rationality - another modernist axiom - and the exercise of reason enables a person to decide 'who he is, what he wants, what his interests are and how they may best be pursued' (sic) (Slater, 1997, p. 39). These characteristics have become essential to any notion of personal liberty or freedom. This view of consumers is not one that many progressive marketing or consumer behaviour theorists would subscribe too anymore, yet this conceptualisation remains foundational to contemporary political economy. For example, Willmott (1999) has criticised this rationalistic, atomistic view on several accounts. First, it promotes a view of market relationships based on calculated cost and benefits. This is clearly problematic when choice is recognised to be emotional (Elliott, 1998) and even fantastical (see Holbrook and Hirschman, 1982). Second, because individuals are not given any social identity, there can be at best an inadequate acknowledgement of asymmetrical relations of power between consumers. This is particularly significant because it leads to markets that favour those who are able to exercise more choice thereby increasing any inherent inequalities that already exist. Freedom through choice and material progress is available, but only to those who can participate in the market by selling their labour power, renting their capital, or otherwise drawing on stored capital - economic, social and cultural (Bourdieu, 1984) - and this is rarely equally distributed amongst a given population.

In summary, from a neo-liberal perspective, power is understood as a thing that can be owned, acquired or lost; something which may be exercised by someone who has 
power over someone who does not. Conceptualising power in this way has the effect of objectifying power, with power existing independently of the subject and acting upon it. This view also implies that subjects are taken as given. In contrast to this traditional approach, Foucault does not take as presupposed this version of the subject or of power. Rather, Foucault's work demonstrates an alternative approach to power relations, and the possibility for a more developed theory of consumer empowerment.

\section{Foucault and Power}

To be dominated by power external to oneself is a familiar and agonizing form power takes. To find, however, that what "one" is, one's very formation as a subject, is in some sense dependent on that power is quite another. We are used to thinking of power as what presses on the subject from the outside... But if, following Foucault, we understand power as forming the subject as well... then power is not simply what we oppose but also... what we depend on for our existence...

Butler (1997: p. 1-2, original italics).

Foucault rejects the existence of essential interests, enduring desires, rationality, or any aspect of subjectivity for that matter, as existing independently of society. For him, subjects are socially constructed within discourses. In his genealogical studies, Foucault uses the term discourse to mean more than just written or spoken language; discourses are ways in which bodies of knowledge are produced, circulated and come to define our ways of knowing by objectifying power relations. Power is related to knowledge in the sense that power generates the discourses that limit and define what is knowable. Foucault uses the term power to describe the historical circulation of this social construction. Power generates discourses of various rules and norms that are embedded in society; not only in prisons, politics, schools, or religion, but also in fashion, 
public opinion, entertainment, sports, news, information, family, and even subjects' relations to themselves. Contrary to the definitions discussed above, power does not emanate from somewhere or someone but is distributed throughout society; "[it] traverses and produces things, it induces pleasure, forms knowledge, produces discourse" (Foucault 1980: p. 119). In this view, power is not a thing that is owned or lost, given away or acquired, say from producers to consumers. Rather power produces both producers and consumers within discourses of knowledge - economic, political and managerial - through which power circulates. Foucault's views emphasize that power cannot be captured in a dualism of those who have it versus those who don't, the oppressor versus the oppressed, the employer over the employee, producers over consumers. Neither consumers nor producers can simply own or lose, give away or acquire power. The notions of 'consumers' as well as 'producers' take place within broader discourses of knowledge through which power circulates.

Foucault's investigation into the functioning of power/knowledge between premodern and modern societies draws attention to the distinctive features of such discourses. For him, the role of power in creating social practices and forms of discourses in modern societies rests upon the use of technologies that is physical and material practices with transformative functions. In Foucault's early work, he focused on a disciplinary power exercised through technologies of domination to create disciplined subjects. In Discipline and Punish, Foucault (1977) describes a society in which individuals are rendered disciplined, obedient, and normal through constant observation, measurement, and threat of exclusion or corporal punishment. Foucault begins by describing the torture and execution that took place in pre-modern Europe. This was an 
exercise in domination through fear generated by such public displays of torture and barbarity. However, as populations grew and villages became cities, local surveillance on each individual became less possible and corporal means of control exercised externally by a centralised power became less effective. According to Foucault, the modern concept of power becomes inscribed and begins to operate in discourses and language structures. It is no longer external threats or constraints that enforce disciplinary power. It is through this observation that Foucault (1977: p. 102) suggests, "the mind becomes a surface of inscription for power", allowing us an insight into the direction his theory on power would take in the future.

In the context of this paper, the identities of people as consumers have been substantially defined by the neo-liberal project and the discursive practices of marketing such as those of advertising, branding and other promotional discourses. These discourses have provided the standards of norms and have colonized many aspects of our daily life, glimpses of possible selves to aspire to and emulate through consumption. Once upon a time the primary agents of socialization were institutions like the family, school, church etc., but now consumption is a prime socialization agent whereby people are taught how and learn to be consumers.

\section{From Governmentality to Technologies of Self}

In his later work Foucault traces the gradual progression from external control, to control and discipline exercised by individuals upon themselves. The individual increasingly experiences his or her life as an exercise in which one's own action dictates success or failure. This outcome is achieved through recourse to similar knowledge 
systems and the process represents a theoretical attempt to join macro-level politics to the micro-level of the individual (Foucault, 1984). Rather than external discipline then, Foucault argues that it is the pursuit and creation of knowledge itself, which, by creating norms and standards, helps form a disciplined subject. In his early work, Foucault characterizes these knowledge systems as totalizing and individualizing techniques (Foucault 1983). First, they are totalizing in the sense that knowledge systems are used in all of day-to-day human practices. For example, they are inscribed in the name of health (medicine), knowledge (school) and reform (politics), rendering power omnipresent. Such omnipresent power brings all thoughts, beliefs, actions, morals, and desires of individuals towards a norm that is acceptable. People who diverge from the norm face social pressure to conform, standardise, and normalise. The knowledge systems adopted to teach children, regulate workers, and educate consumers have been generalised to a society as a whole; there is no escaping from it.

Second, knowledge systems are individualizing as the idea of normality and hence abnormality becomes increasingly clear and more rigorously defined. As power is inscribed in all social practices, the notion of normality in terms of the body, behaviour, attitude, or disposition becomes more apparent, and the ones who do not fit in are easier to identify. The individuals who are not rational, responsible and disciplined subjects are pushed to the margins, and as such, become the target for more control and discipline. Thus, in forging a particular kind of subject, the exercise of power creates an opposition between good and evil, us and them, civilization and barbarism. This discourse of good and evil legitimates any actions undertaken in the name of good and marginalizes those 
performed by the "others". This system of marginalization forges a kind of identity, which serves for more discipline.

In considering how such a process could be experienced, Rose $(1998,1999)$ regards the process of governmentality to be central to the effective disciplining of the sovereign subject. Governmentality is the result of Foucault's linking of the French, "gouverner" (governing) and "mentalité" (modes of thought). Well into the $18^{\text {th }}$ century government was not only processes of the State but also, 'designated the way in which the conduct of individuals or groups might be directed'; to govern 'is to structure the possible field of action of others' (Foucault, 1982, p. 221) and includes governing through technologies of domination, as well as methods of governing the self (Foucault, 1982; Lemke, 2002). Though Foucault began to develop his notions of governmentality later in his life, governmentality may be regarded as occurring between external domination and self-government; between technologies of domination and technologies of self. Rose's studies in particular focussed on the role of the 'psy' sciences psychology, psychiatry and psychotherapy - and the way these disciplinary discourses not only construct knowledge about what it is to be a person but also how these discourses then constitute what is knowable about people and therefore what people have to do in order to be fully functioning, efficient and happy.

In the context of marketing and consumption, this Foucauldian account suggests that people have become disciplined as consumers through the effect of knowledge systems exercised via governmentality. This notion is useful in discussing how the authoritative realm learns about and forges self-disciplined consumers. For example, alongside political and economic discourses - neo-classical economic theory and the neo- 
liberal project - advertising and promotional discourses may be seen to represent a progressive colonization of the life-world by the marketplace or as Ringmar (2005: p.12) terms it the "shopping-mallization" of everyday life. Campbell (2004) even goes as far as to suggest that personal ontology relies on acts of consuming - we discover ourselves by exposure to consumables. Consumers are thus enmeshed in relations of power with producers (brand owners, market research agencies, advertisers etc.) who through an educative process, shape the consuming subject. In other words, the subjectivities or identities of consumers are the effects of power when people are conceptualized as consumers and participate in consumption practices regulated by markets.

Nevertheless, this is not to say that power remains a top down exercise for disciplining docile subjects. Laclau (1990) observes that subjects viewed as the product of top-down structures infer a deterministic view of social relations. Such a view is problematic in relation to the work of De Certeau (1984) and Fiske (1989) for example, who assign more agency to consumers; moreover, Foucault himself regarded this deterministic standpoint as problematic in relation to political resistance. Indeed, for Foucault, "freedom" is an essential element in the relation between government and governed, and he makes it clear that wherever there is power, there is also resistance (Foucault, 1990; see also Best and Kellner, 1991). Foucault understood a need for a theory that recognised the creative power of the subject as actor. Starkey and McKinlay (1998: p. 236) observe how Foucault's later emphasis "shifted from the normalisation of populations to the choices that are possible in small groups ... who band together to create their own models of thinking and behaviour within their own communities". This observation suggests a theoretical shift from the ways 'individuals are transformed by 
others to the ways in which individuals transform themselves' (Best and Kellner, 1991: p. 55). In this project Foucault began to consider technologies of domination to be joined by technologies of self (Foucault, 1986).

Technologies of self emphasize the socially constructed mechanisms through which people understand and experience themselves as subjects. This effect is a result of such power relations that encourage persons to conceive of their own identity and observe themselves so that they might mediate their practices in the pursuit of life as an aesthetic pursuit, 'a self which has to be created as a work of art' (Foucault 1984b: p. 362). Here Foucault refers to a notion of truth and ethics that form a kind of moral imperative shared by a particular group. In the context of the present study, consumption can be regarded as having become one of the many technologies of self, a site of selfcreation, or self-care (Firat and Venkatesh 1995; Rose 1998). For example, Du Gay (1996: p. 76-77) observes that,

As 'consumers' people are encouraged to shape their lives by the use of their purchasing power and to make sense of their existence by exercising their freedom to choose in a market... Within the discourse of enterprise/excellence consumers are constituted as a autonomous, selfregulating and self-actualising individual actors seeking to maximise their 'quality of life' - in other words to optimise the worth of their existence to themselves - by assembling a lifestyle or lifestyles through personalised acts of choice in the market place.... freedom and independence emanate not from civil rights but from individual choices exercised in the market.

On the one hand, such regulation may be viewed as another form of domination through governmentality. Rose $(1998,1999)$ for example, shows that whilst persons may be increasingly subjective, self-governing beings, their subjectivity is the concern of organizations and governments and that these powerful groups may to a certain extent 
tailor the desires of self-governing subjects to favour the needs of corporations and markets. Thus how an individual conceives of him or herself as a moral, consuming subject remains largely a dictate of the neoliberal/ enterprise culture (Du Gay, 1996). On the other hand, the consuming subject's ability and wishes to exercise choice, though perhaps constructed through governmentality, might also be partially severed from dominant ethic or the neoliberal enterprise culture. If this is the case, technologies of self may also transform individuals and partially liberate them from previous cultural circuits. With this notion, Foucault observes the possibility to create new privileged spaces, and indeed, he infers that the result of such practice may endow the individual with happiness, purity, wisdom, and perfection (Foucault, 1986). Once this is achieved, the imperatives and models of discipline imposed in a disciplinary sense may to some extent be transcended. To an extent, Foucault regarded this as a property of social elites (Rabinow, 1991), but as we show later in this paper, such spaces for emancipation and criticism have become an increasingly common and high profile feature of the contemporary marketing landscape.

\section{A Foucauldian Notion of Consumer Empowerment}

We would argue that marketing discourses or 'technologies of consumption' (Rose, 1999: p. 271) can be conceived in Foucauldian terminology as both technologies of domination and technologies of self: at once disciplining and liberating. On the one hand, marketing practices like segmentation, targeting, database and direct marketing, customer relationship management, loyalty cards etc., are disciplinary mechanisms that can be regarded as transforming a heterogeneous mass of people into more homogeneous 
market segments such that people can be categorized, surveyed and targeted as consumers. On the other hand, people when interacting with marketing practices like branding, customizing and prosumption may also construct and re-construct their identities, or possible selves (Markus \& Nurius, 1986) at will by consuming the appropriate brands or experiences (Elliott and Wattanasuwan 1998; Firat and Venkatesh, 1995).

The consumer can thus be construed as a point of articulation or alignment between the discourses of capitalism, neo-liberalism and neo-classical economics on the one hand with the search for a 'meaningful' self through consumption on the other. There emerges a paradox: not only are people expected to choose, but they are forced to choose in order to be 'free' (Rose, 1999). For Rose (1999: p. 261-262) power is the relation between the regulation of consumers, by others and themselves, such that they are 'consonant with contemporary political principles, moral ideals and constitutional exigencies'. People, by being turned into consumers and by becoming consumers themselves, 'have become attached to the project of freedom.' The liberal project thus manifests itself by encouraging people to 'self-manage' through rational choices that they make for themselves, organising these choices around the operations of markets and conflating this choice to freedom (see Du Gay, 1996). The disciplining of people as consumers and the liberation or empowerment of people through consumption are, so to speak, two sides of the same coin.

This view of power suggests that the empowerment of consumers, as a technology of self, may manifest itself when consumers feel that the market relations into which they enter are not conducive to this overall project; when the logic of market relations does not 
deliver on its promise of improving the quality of their lives for example. Alternatively, consumer empowerment can also manifest itself when people self-manage themselves through consumption. As Kozinets (2002) has argued, it is not possible, in any meaningful sense, to escape market relationships; rather people can inhabit emancipated spaces and resistance and empowerment may take place within the logic of the market (Peñaloza and Price, 1993). For some, these spaces are transient and localized (see Goulding et al, 2002; Kozinets, 2002) - a temporary negation or distancing from dominant and perhaps repressive subjectivities that emerge from other market based relations. Others may fully commit to a consumption lifestyle so long as it continues to deliver a positive subjectivity, i.e. people 'like' being consumers (or at least they continue to think they do).

For the remainder of the paper we shall discuss some marketing theory and practice implications, and some directions for further research that emerge when a traditional reading of empowerment, presented in the first part of the paper, is contrasted with a Foucauldian interpretation. In particular we will briefly continue with our examination of the neo-liberal axiom that choice equals freedom and therefore empowerment. As Hodgson (2001: p. 125) points out from a Foucauldian perspective, 'freedom is constructed through the operation of power'. Then we examine some examples of the responses of organizations when their consumers inhabit emancipated spaces and exercise resistance to power.

\section{Consumer Empowerment Through Choice?}


An emerging problem with the neo-liberal project of advanced industrialized economies is that as the levels of affluence and prosperity have increased it becomes more difficult to deliver on their (implicit) axiological assumptions of greater happiness and increased well-being - the point, as we have previously argued, of having more choice and therefore a primary motivation for empowering consumers. Numerous studies from across the social sciences have demonstrated that people, having been encouraged to consume, are in fact not any happier than they were 50 or so years ago. There exists little evidence to suggest that an increase in material well-being leads to an increase in subjective well-being, over and above a minimum threshold that varies from country to country, culture to culture and that has been achieved by many in advanced industrialized societies (Csikszentmihalyi, 1999; Diener, 2000; Myers, 2000). Economists too have provided similar evidence and also conclude that in countries that have experienced economic growth and rising average incomes, the number of people saying they are happy with life has increased very little (Hirsch, 1976; Layard, 2005; Oswald, 1997; Scitovsky, 1976).

A recent report from the UK government funded National Consumer Council (Bush, 2004) identifies that despite the theoretical promise that more markets and more choice will benefit consumers, the opposite often appears to be the case. More choice often makes choice harder not easier for consumers. From the perspective of the rational consumer, if indeed one exists, this can be attributed to the need for consumers to process more and more information in order perform efficiently. When the cost of processing all this information outweighs the benefit, inertia or choice paralysis sets in. Alternatively, as the number of choices increase, so does the potential of making the wrong choice and 
people become less happy, content or sure about the choice they do make and this may be experienced as a sense of regret in terms of those choices that they have rejected (see Schwartz, 2004; Wathieu et al 2002).

Choice or the freedom to choose is, in this case, a double-edged sword and although it can be empowering or liberating, exercising choice can also be chaotic and paralysing (Schwartz 1994; 2000; 2004). With an increasing amount of choice, both within markets and as the total number of markets increases, the inability to make a choice, or choosing when to choose, or choosing when to be a consumer, will become more common aspects of everyday life (see for example Mick, Broniarczyk and Haidt's (2004) notion of hyperchoice). In some markets choice is actually disempowering rather than empowering. In the financial service markets for example, info-mediaries like independent financial advisors, often operate by reducing choice and offering a limited portfolio to their clients. Producers are also adept at increasing the switching costs for consumers, and for many people they simply cannot be bothered to shop around for the best mortgage, mobile phone or credit card deal. In the privatized utilities markets despite increased competition low-income consumers are often paying more for their utilities than the already affluent (Bush, 2004). Contrary to the dominant economic paradigm 'knowing' when our utility has been maximized is in reality rather difficult: rational choice can be conceived of as a technology of domination.

So, how should marketers, theoreticians and practitioners, respond to the choice paradox? Theoretically, Shankar and Fitchett (2002) have suggested that marketers should seriously entertain the thought that consumers will reject the discourse of having. Rather, and drawing on the ideas of Erich Fromm, they suggest a 'marketing of being': 
goods and services will be valued by consumers on the basis of their ability to facilitate a positive sense of being and identification. Furthermore, being is very much a social process; whoever we are trying to be requires social validation. Evidence of a 'marketing of being' can be found in the relationship marketing literature (Shankar and Fitchett, 2002). Further research could investigate how the discursive practices of marketing that currently constructs people as insatiable, desiring consumers (Belk et al, 2003) can be reformulated. If, as Cova (1997) has argued, the goods and services that will be successful are those that bring people together and have 'linking value', perhaps promotional appeals could focus on the social benefits of goods and services rather than focus on appeals to the narcissistic self (Lasch, 1979). Increasingly, we are seeing retail environments or servicescapes constructed that are experiential, emphasizing that the discourses of consumption can be represented and constructed to be more emotional and less rational.

Practically, an example of the choice paradox has implications for supermarket retailers. Further research should seriously reconsider retailer category management techniques as they seek to maximize shelf space turnover, profitability and shopper loyalty. In a product tasting study by Iyengar and Lepper (2000), when choice was limited to tasting between six alternatives, people were more likely to buy one of the products they tasted than when they were faced with 24 alternatives. Moreover those with limited choice also reported to be more satisfied with their choice. More choice can actually be demotivating and so restricting choice within the supermarket environment could actually increase turnover, make shoppers more content with the shopping experience and potentially more loyal as a result. 
In response to more and more choice, a growing number of people are choosing to consume less and self-control their expenditure. From a Foucauldian technology of self perspective, in choosing to choose less, empowerment involves the withdrawal from relations that construct people as consumers. This 'less is more' consumer movement is often recognized as the voluntary simplicity or downshifting phenomenon. In a recent study $25 \%$ of British adults aged between 30 and 59 claimed to have downshifted in the past 10 years (Hamilton, 2003). In this study downshifting was defined as a voluntary long-term change in lifestyle that has resulted in a reduction of earning potential. And contrary to myth it is not just the materially well off who downshift, rather it occurs across the entire socio-economic spectrum (Hamilton, 2003). A key trait of downshifters is their determination to 'have more time, less stress and more balance' in their lives (Schor, 1992: 117). Downshifters do not escape the market rather they engage in market relationships that are more likely to involve sharing, communal relations rather than formal, contractual, socially distanced relations (see Kozinets, 2002). When shopping for groceries to supplement what they grow themselves, downshifters may be more likely to go to their local farmers market or subscribe to an organic box delivery scheme than pop down to their local, multinational supermarket.

The jury then still appears to be out on whether consumer empowerment through more choice is beneficial. To be sure some choice is beneficial but the benefits appear to diminish as the depth and breadth of choice increases. If anything, our analysis has highlighted the questionable assumptions that underpin the neo-liberal project of governmentality upon which this logic is predicated. We now turn our attention to the implications for organizations of empowered consumers. 


\section{Empowered Consumers and Organizational Response}

If it is questionable whether consumers benefit from some forms of empowerment, do organizations benefit from more empowered consumers? Certainly governments would like to empower consumers. In 1999, the UK government produced a 62-page White Paper entitled "Promoting Performance, Providing Protection", the gist of which is that the UK government wants its citizens to become 'better' consumers to improve the performance of the organizations that make up the enterprise culture (Du Gay, 1996) and thus constitute 'UK plc'. More efficient and competitive markets will increase the efficiency of the suppliers in these markets with consumers becoming the fulcrum around which these efficiencies revolve.

Organizations, of course, want loyal consumers too, at least according to conventional marketing theory as loyalty increases profitability. A recent study by Muniz and Schau (2005) looked at how consumers of a brand of Personal Digital Assistant or PDA - the Apple Newton - continued to worship the brand, literally, even though the brand has been discontinued. They were so loyal in fact, that they continued modifying, repairing and innovating the product long after it had been withdrawn by Apple in 1998 . The religiosity connected with this Apple product taps into and propagates the generic and iconic Apple brand mythology - Apple devotees are brand advocates or preachers of the highest order. The generic Apple brand has countercultural values based in large to its positioning against Microsoft that emphasize its uniqueness and non-conformity (Belk and Tumbat, 2001; Muniz and Schau, 2005). Apple however is encountering problems. Its loyal consumer base appears to be growing increasingly disaffected, in part because it 
is becoming a mainstream brand through the success of its iPod range (that now accounts for nearly a third of its turnover), but also because product quality is being compromised.

The Internet has become a medium for loyal Apple consumers to air their discontent. These highly computer literate consumers are empowering themselves by expressing their disgruntlement through an increasingly popular vehicle: web-logs, more commonly know as 'blogs'. America On Line estimates that nearly half of all bloggers are blogging as a form of therapy - a confessional medium in which to air and share their hang-ups and anxieties. Blogs are online journals - the $21^{\text {st }}$ century equivalent of the diary - that mix personal opinion and observations with links to other sources of information on the net. The blogger, the person whose blog is read, often allows for readers to contribute their own thoughts and reactions in a blog chain. Blogging is now so popular that Google has a special blog search capacity. Apple's iPods have become the latest must-have accessory and have been credited with improving the fortunes of the parent company. However according to the bloggers there are serious design faults associated with the entire product range that include the battery not recharging properly and the screen on the new iPod Nano breaking easily. Below is a blog from an anti-Apple website (http://jobqosusa.blogs.com/jobqos/2005/08/apple_iproduct.html. Accessed 12/10/05). 


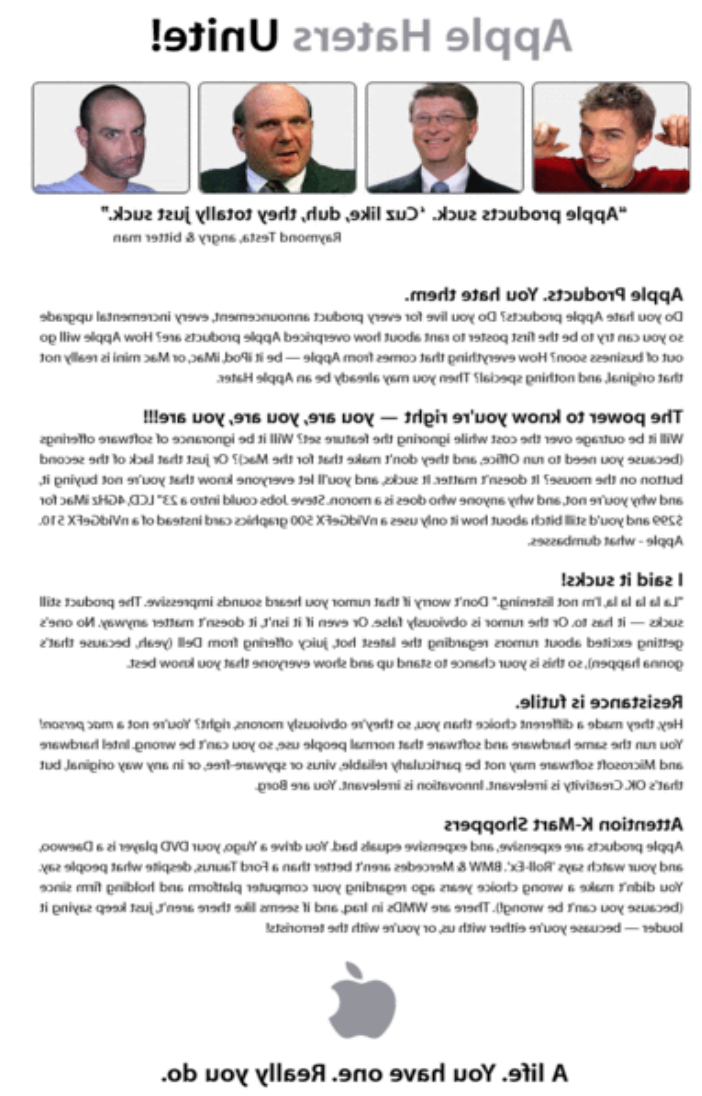

And what has Apple's reaction been to bloggers? Much to the complete astonishment of it loyal devotees, Apple is behaving like its arch nemesis Microsoft and taking a blogger to court, literally invoking a form of disciplinary power (see http://www.psfk.com/2005/01/antiapple_the_w.html. Accessed 12/10/05). What effect this will have in the long term is unclear. However it does seem that for whatever reason there is something seriously wrong with Apple's new product development process and products are being launched into the marketplace before any potential technological problems have been completely ironed out. Again this is a more of a characteristic of its rival Microsoft. One iPod Nano customer Matthew Peterson, was so incensed with the poor quality of his iPod that he set up a website to display pictures of his and others, broken iPod screens. Eventually Apple responded to this consumer concern and 
announced that it would compensate disgruntled consumers but not before the stockbroker Merrill Lynch had downgraded its shares from 'buy' to 'neutral'.

Other companies like General Motors have introduced their own 'official' blogging sites, whilst others like Mazda and Doctor Pepper's have gone as far as to recruit bloggers to blog in favour of their products (Graves, 2005). This merely demonstrates how some organization are simply uncomfortable with the idea of consumers freely expressing their opinions about their products and want to control what is said and by whom. They appear to find it hard to relinquish their disciplinary power, whilst concurrently consumers have an accessible medium and a willing audience in which to demonstrate their creative empowerment. Hence blogging might be conceived of as a medium through which technologies of self may operate. Bloggers are empowered to set up their own communities with alternative ethics to those of the parent company. With these ethics they are able to pursue their goals with reference to their own moral sentiments and agendas.

\section{Conclusion}

That consumers can be, should be or even need to be empowered appears, at least at face value, to be foundational to any organization purporting to have a marketing orientation and to the effective and efficient operation of advanced industrialized economies. Empowering consumers is often equated in practice to giving people more and more choice. In turn, this reproduces liberal humanist notions of power and continues to promote the view of 'people as consumers' as calculating utility maximizers. However, we have outlined how power is dispersed throughout a myriad of interconnecting 
discourses as a 'multiple and mobile field of force relations,' (Foucault, 1980: p. 102). And as we have suggested from this perspective, more choice does not necessarily result in consumer empowerment.

Foucault (1982a: p. 208) considered that his most important intellectual contribution was his lifelong project, 'to create a history of the different modes by which in our culture human beings are made subjects'. We have outlined the role of technologies of domination, whilst in his later work, Foucault emphasizes that, although disciplinary power is productive of subjects, it does not eradicate the subject's capabilities for critical self-reflexivity through technologies of self. The link between these two technologies can be conceptualized using Foucault's notion of governmentality in creating the self-disciplined subject that is central to the neo-liberal project. (Lemke, 2002; Rose 1998, 1999). Rose (1999) notes that for this reason, the management of self has become central to organizations and government and in this way technologies of the self can be viewed as internalized extensions of a dominant disciplinary power. Nevertheless, Foucault writes about the possibilities of being and living "at the frontier" (Foucault 1984a: p. 46), of thinking outside of the knowledge systems which frame us. Empowerment may exist through technologies of self; the techniques 'which permit individuals to effect by their own means or with the help of others a certain number of operations on their bodies and souls, thoughts, conduct and way of being, so as to transform themselves in order to attain a certain state of happiness, purity, wisdom, perfection, or immortality' (Foucault, 1988: p.18). What appears to be at stake here is the shared version of ethics objectified as knowledge through discourses; this is the knowledge of the aesthetics of life that encourage any particular group to actively engage 
with the world. In the context of the present study, through practices such as downshifting and via media such as the Internet, groups of consumers are able to recreate such discourses, offering alternative ethics and moral imperatives. As such, the constitution as self and the action of self-governing subjects who seek an aesthetic life suggests patterns of conduct liberated from the traditional top-down conceptions of a dominating marketplace. In this context, the practices of downshifters and bloggers constitute an interstitial zone between the macro-politics of marketers, and the desires and ethics of socialised and increasingly emancipated consumers.

Are these observations signs of the denegation of or the resistance to neo-liberal forms of governmentality? Certainly for some organizations, empowered consumers have become problem consumers. But is this evidence of a shift in power relations further towards truly self-constituting subjects? Perhaps not, for there remains the alternative that such formations and other supposedly emancipated or autonomous enclaves, may themselves, to variable extents, be regarded as products of the totalizing power of the market (Rose, 1999; Du Gay 1996). In this sense Foucault's axiom, where there is power there is always the possibility of resistance, may be read as suggesting that where there is empowerment there will also be disempowerment: in such a scenario resistance merely supports domination, "for it hides the real working of power." (Dreyfus and Rabinow, 1983: p. 169).

\section{References}

Alvesson, M. and Willmott, H. (eds.) (1992), Making Sense of Management: A Critical Introduction, London: Sage. 
Alvesson, M. and Deetz, S (2000), Doing Critical Management Research, London: Sage. Berlin, I. (1969), Four Essays on Liberty, Oxford: Oxford University Press.

Belk, R. W., Ger, G. and Askegaard, S. (2003), “The Fire of Desire: A Multisited Inquiry into Consumer Passion," Journal of Consumer Research, Vol 30 December, pp. 326-351.

Belk, R.W. and Tumbat, G. (2002), The Cult of the Macintosh, Salt Lake City: University of Utah, Odyssey Films.

Best, S. and Kellner, D. (1991), Postmodern Theory: Critical Interrogations, London: MacMillan Press.

Boje, D. M. and Rosile, G. A. (2001), "Where's the Power in Empowerment? Answers from Follett and Clegg,” Journal of Applied Behavioral Science, Vol 37 No 1, pp. 90-117.

Bourdieu, P. (1984), Distinction: A Social Critique of the Judgement of Taste, London: Routledge.

Brown, S. (1995), Postmodern Marketing, London: Routledge.

Brownlie, D., Saren, M., Wensley, R. and Whittington, R. (1999a), "Marketing Disequilibrium" in Brownlie, D., Saren, M., Wensley, R. and Whittington, R. (eds.), Rethinking Marketing: Towards Critical Marketing Accountings, London: Sage, pp. 1-22.

Brownlie, D., Saren, M., Wensley, R. and Whittington, R. (eds.)(1999b), Rethinking Marketing: Towards Critical Marketing Accountings, London: Sage.

Burton, D. (2001), “Critical Marketing Theory: The Blueprint?” European Journal of Marketing, Vol 35 No 5/6, pp.722-743. 
Bush, J. (2004), Consumer Empowerment and Competitiveness, National Consumer Council: London.

Butler, J. (1997), The Psychic Life of Power, Stanford: Stanford University Press. Campbell, C. (2004), "I Shop Therefore I Know That I Am: The Metaphysical Basis of Modern Consumerism," in Ekstrom, K. and Brembeck, H. (eds.), Elusive Consumption: Tracking New Research Perspectives, Oxford: Berg.

Cochoy, F. (1998), “Another Discipline for the Market Economy: Marketing as a Performative Knowledge and Know-how for Capitalism," in Callon, M. (ed.) The Laws of the Markets, Oxford: Blackwell, pp. 194-221.

Cova, B. (1997), "Community and consumption: Towards a definition of the "linking value" of product or services," European Journal of Marketing, Vol 31 No 3/4, pp. 297-316.

Csikszentmihalyi, M. (1999), “If We Are So Rich, Why Aren’t We Happy?” American Psychologist, Vol 54 No 10, pp. 821-827.

De Certeau, M. (1984), The Practice of Everyday Life, Berkley: University of California Press.

Desmond, J. (2003), Consuming Behaviour, Basingstoke: Palgrave.

Dholakia, N. and Dholakia, R. R. (1985), "Choice and Choicelessness in the Paradigm of Marketing," in Dholakia, N. and Arndt, J., (eds.), Changing the Course of Marketing: An Alternative Paradigm for Widening Marketing Theory, Greenwich CT: JAI Press, pp. 173-185.

Diener, E. (2000), “Subjective Well-Being: The Science of Happiness and a Proposal for a National Index," American Psychologist, Vol 55 No 1, pp. 34-43. 
Dreyfus, H. L. and Rabinow, P. (eds.), (1983) Michel Foucault: Beyond Structuralism and Hermeneutics, Hemel Hempstead: Harvester Press,

Du Gay, P. (1996), Consumption and Identity at Work, London: Sage.

Elliott, R. (1998), “A Model of Emotion-Driven Choice,” Journal of Marketing Management, Vol 14 No 1/3, pp. 95 -108.

Elliott, R. and Wattanasuwan, K. (1998), "Brands as symbolic resources for the construction of identity," International Journal of Advertising, Vol 17, pp. 131144.

Fiske, J. (1994), Understanding Popular Culture, London: Routledge.

Firat, A. F. and Venkatesh, A. (1995), "Liberatory Postmodernism and the Reenchantment of Consumption," Journal of Consumer Research, Vol 22 December, pp. 239-267.

Foucault, M. (1977), Discipline and the Punish: The Birth of the Prison, Translated by Alan Sheridan, New York: Random House.

Foucault, M. (1980), “Truth and Power,” in Colin Gordon, C. (ed), Power/Knowledge: Selected Interviews and Other Writings 1972-1977, New York: Pantheon, pp. Foucault, M. (1983), “The Subject and Power,” in Dreyfus, H. L. and Rabinow, P. (eds.), Michel Foucault: Beyond Structuralism and Hermeneutics, Hemel Hempstead: Harvester Press, pp. 208-226.

Foucault, M. (1984a), "What is Enlightenment?" in Rabinow, P. (ed) The Foucault Reader, New York: Pantheon.

Foucault, M. (1984b), "On the Genealogy of Ethics: An Overview of Work in Progress," in Rabinow, P. (ed) The Foucault Reader, London: Penguin, pp. 340-372. 
Foucault, M. (1988), “Technologies of Self” in Martin, L. H., Gutman, H. and Hutton, P. H. (eds.) Technologies of Self, London: Tavistock, pp. 16-49.

Foucault, M. (1986), The Uses of Pleasure: A History of Sexuality Volume II, Harmondsworth: Viking.

Foucault, M. (1990), The History of Sexuality Volume I: An Introduction, London: Penguin.

Friedman, M. with Friedman, R. (1962), Freedom and Capitalism, Chicago: Chicago University Press.

Friedman, M. and Friedman, R. (1980), Free to Choose: A Personal Statement, New York: Harcourt Brace.

Goulding, C., Shankar, A. and Elliott, R. (2002)“Working Weeks, Rave Weekends: Identity Fragmentation and the Emergence of New Communities." Consumption, Markets and Culture, Vol 5 No 4, pp. 261-284.

Graves, C. (2005), “The Executive’s Bloggers Guide,” Ogilvy Insights, Ogilvy Public Relations Worldwide.

Hamilton, C. (2003), "Downshifting in Britain: A Sea-change in the Pursuit of Happiness," Discussion Paper Number 58, Canberra: The Australia Institute.

Hirsch, F. (1977), Social Limits to Growth, London: Routledge.

Hodgson, D. (2001), “Empowering Customers Through Education or Governing without Government," in Sturdy, A., Grugulis, I. and Willmott, H. (eds.), Customer Service: Empowerment and Entrapment, Basingstoke: Palgrave, pp.117-134. 
Iyengar, S. and Lepper, M. (2000), "When Choice is Demotivating: Can One Desire Too Much of a Good Thing?" Journal of Personality and Social Psychology, Vol 79, pp. 995-1006.

Kasabov, E (2004), “Power and Disciplining: Bringing Foucault to Marketing," Irish Marketing Review, Vol 17 No 1/2, pp. 3-12.

Kozinets, R. (2002), “Can Consumers Escape the Market? Emancipatory Illuminations from Burning Man," Journal of Consumer Research, Vol 29 June, pp. 20-38.

Lasch, C. (1979), The Culture of Narcissism, New York: W.W. Norton.

Laclau, E. (1990), New Reflections on the Revolution of Our Time, London: Verso.

Layard, R. (2005), Happiness: Lessons From a New Science, London: Penguin.

Lemke, T. (2002), "Foucault, Governmentality, and Critique," Rethinking Marxism, Vol 14 No 3, pp. 49-64.

Lincoln, N. D., Travers, C., Ackers, P., and Wilkinson, A. (2002), “The meaning of empowerment: the interdisciplinary etymology of a new management concept", International Journal of Management Reviews, Vol 4 No 3, pp. 271-290.

Markus, H. and Nurius, P. (1986), "Possible Selves," American Psychologist, Vol 41 No 9, pp. 954-969.

Marsden, D. (2001), “Disciplinary Power and Consumer Research,” European Advances in Consumer Research, Vol 5, pp. 54-60.

Mick. D.G., Broniarczyk, S. M. and Haidt, J. (2004), "Choose, Choose, Choose, Choose, Choose, Choose, Choose: Emerging and Prospective Research on the Deleterious Effects of Living in Consumer Hyperchoice," Journal of Business Ethics, Vol 52, pp. 207-211. 
Morgan, G. (1992), "Marketing Discourse and Practice: Towards a Critical Analysis," in Alvesson, M. and Willmott, H. (eds.) (1992), Making Sense of Management: A Critical Introduction, London: Sage, pp. 136-158.

Muniz, A. M. Jr., and Schau, H. J. (2005), "Religiosity in Abandoned Apple Newton Brand Community," Journal of Consumer Research, Vol 31 March, pp. 737-747.

Myers, D. G. (2000), “The Funds, Friends, and Faith of Happy People," American Psychologist, Vol 55 No 1, pp. 56-67.

Oswald, A. J. (1997), “Happiness and Economic Performance,” Economic Journal, Vol 107, pp. 1815-1831.

Peñaloza, L. and Price, L.L. (1993), “Consumer Resistance: A Conceptual Overview,” Advances in Consumer Research, Vol 20, pp. 123-128.

Ringmar, E. (2005), Surviving Capitalism, London: Anthem Press.

Rose, N. (1998), Inventing Our Selves: Psychology, Power and Personhood, Cambridge: Cambridge University Press.

Rose, N. (1999), Governing The Soul: The Shaping of The Private Self, $2^{\text {nd }}$ ed. London: Free Association Books.

Samli, A. C. (2001), Empowering the American Consumer: Corporate Responsiveness and Market Profitability, Westport: Quorum Books.

Schwartz, B. (1994), The Costs of Living: How Market Freedom Erodes the Best Things in Life, New York: W. W. Norton.

Schwartz, B. (2000), “Self-Determination: The Tyranny of Freedom,” American Psychologist, Vol 55 No1, pp. 79-88.

Schwartz, B. (2004), The Paradox of Choice, New York: Ecco. 
Schor, J. (1992), The Overworked American: The Unexpected Decline of Leisure, New York: Basic Books.

Scitovsky, T. (1976), The Joyless Society, Oxford: Oxford University Press.

Shankar, A. and Fitchett, J. (2002), "Having Being and Consumption," Journal of Marketing Management, Vol 18 No 5/6, pp. 501-516.

Slater, D. (1997), Consumer Culture and Modernity, Cambridge: Polity Press.

Starkey, K. and McKinlay, A. (1998) "Deconstructing Organisation - Discipline and Desire" in Starkey, K. and McKinlay, A. (eds.) (1998) Foucault, Management and Organisation Theory, London: Sage.

Wathieu, L., Brenner, L., Carmon, Z., Drolet, A., Gourville, J., Muthukrishnan, A., Novemshy, N., Ratner, R., Wu, G. (2002), “Consumer Control and Empowerment: A Primer," Marketing Letters, Vol 3 No 3, pp. 297-305.

Willmott, H. (1999), “On the Idolization of Markets and the Denigration of Marketers: Some Critical Reflections on a Professional Paradox", in Brownlie, D., Saren, M., Wensley, R. and Whittington, R. (eds.), Rethinking Marketing: Towards Critical Marketing Accountings, London: Sage, pp. 205-222. 